\title{
Kemampuan Penalaran Mahasiswa dalam Memecahkan Masalah pada Mata Kuliah Telaah Kurikulum Matematika Sekolah Menengah
}

\author{
Saddam Al Aziz, Ali Asmar, Defri Ahmad, Fridgo Tasman, Ronal Rifandi \\ Jurusan Matematika, FMIPA Universitas Negeri Padang \\ saddamalaziz@fmipa.unp.ac.id
}

\begin{abstract}
This study aims to analyze the mathematical reasoning abilities of students in the mathematics education study program in the secondary school mathematics curriculum review course. This research was conducted by giving quiz questions in the form of descriptions to a class of students who were then analyzed the answers. The results of the student's answer analysis show that the students' mathematical reasoning ability is still low. The low level of students' mathematical reasoning skills in general lies in the ability of students to analyze problems, make conjectures, determine relationships between variables, and identify links between processes or concepts in a given case. So that many answers from students are not logical and wrong in concluding.
\end{abstract}

Keywords : Mathematical reasoning, Review the secondary school mathematics curriculum, Analyze problem

This is an open access article distributed under the Creative Commons 4.0 Attribution License, which permits unrestricted use, distribution, and reproduction in any medium, provided the original work is properly cited. 12018 by author and Universitas Negeri Padang.

\section{PENDAHULUAN}

Ada beragam macam kemampuan matema tis yang harus dicapai dalam pembelajaran mate matika. Dewan Nasional Guru Matematika (NC TM, 2000:4) menyatakan bahwa ada lima ke mampuan yang harus dimiliki oleh siswa, antara lain kemampuan dalam hal: (1) pemecahan masa lah (problem solving); (2) penalaran dan pembuk tian (reasoning and proof); (3) koneksi (connect ion); (4) komunikasi (communication); dan (5) re presentasi (representation). Oleh karena itu, ke berhasilan dalam pembelajaran matematika mak simal tercapai jika kelima kemampuan tersebut di kuasai dengan baik.

Berdasarkan hal yang dinyatakan oleh De wan Nasional Guru Matematika, maka memiliki kemampuan penalaran matematis yang baik men jadi salah satu tujuan pembelajaran matematis di Indonesia. Hal ini dinyatakan Mendikbud dalam Modul Pelatihan Implementasi Kurikulum 2013 bahwa salah satu kemampuan dalam belajar ma tematika yang penting dikuasai oleh siswa adalah kemampuan menggunakan penalaran pada pola dan sifat, melakukan manipulasi matematika da lam membuat generalisasi, menyusun bukti, atau menjelaskan gagasan dan pernyataan matematika (Aziz, 2018) (Helma, 2017). Kemampuan ini ti dak hanya penting dimiliki oleh siswa saja, na mun juga sangat penting dan khusus dikuasai oleh mahasiswa pendidikan matematika yang me rupakan calon guru (Hidayat, 2020). Oleh karena itu, kemampuan penalaran matematis dijadikan fokus utama dalam penelitian ini.

Penalaran matematis mahasiswa merupa kan bagian terpenting dalam matematika. Hal ini dijelaskan oleh Fahyuddin (2015), menyatakan pentingnya penalaran disebabkan dalam meme cahkan masalah, penalaran digunakan sebagai proses menganalisis hingga diperoleh kesimpul an jawaban. Selain itu, kemampuan penalaran ju ga penting dalam mengembangkan pengetahuan mahasiswa. Sejalan dengan hal tersebut, Riwaya ti (2019), bahwa dalam mengerjakan soal mate matika, mahasiswa selalu menggunakan penala rannya. Dalam menemukan jawaban, mahasiswa pasti berpikir bagaimana menarik kesimpulan berdasarkan apa yang diketahui pada soal dan apa yang dipahami oleh mahasiswa. Pentingnya pena laran matematis juga dihubungkan dengan keter kaitannya dengan kemampuan pemahaman kon sep matematis mahasiswa. Penjelasan dari Dep diknas (Afri,2019) menyatakan bahwa ada keter kaitan yang sangat kuat antara pemahaman kon sep dengan penalaran matematis. Keduanya tidak dapat dipisahkan. Hal ini disebabkan materi mate matika dipahami melalui penalaran dan pena laran dipahami dan dilatihkan melalui belajar ma tematika. Hal ini juga didudukung fakta yang dikemukakan NCTM (2000) bahwa kemampuan penalaran matematis membuat seseorang menge tahui alasan mengapa dia mempelajari matema tika. Selain itu, berbagai cabang ilmu pengeta huan tidak akan berkembang tanpa adanya proses 
penarikan kesimpulan ataupun pembuatan penya taan baru yang bersifat umum (Shadiq, 2004). Jadi, dari beberapa penjelasan tersebut, dapat di simpulkan bahwa kemampuan penalaran matema tis mahasiswa sangat penting diperhatikan.

Kemampuan penalaran matematis adalah kemampuan seseorang dalam menganalisa, me ngaitkan, menduga, hingga membuat kesimpulan berdasarkan konsep-konsep atau informasi yang ada secara logis. Kesimpulan dalam bernalar da pat terjadi dengan membuat pernyataan baru yang didasarkan pada pernyataan sebelumnya dan telah dibuktikan kebenarannya (Sumartini, 2015 dan Alpian, 2020). Kemudian Arigiyati (2017) menambahkan bahwa penalaran merupa kan aktivitas berpikir khusus, di mana terjadi pe narikan kesimpulan dari beberapa premis. Didu kung pendapat Haryono (2018) yang menyatakan dalam artikelnya bahwa penalaran adalah bentuk pemikiran yang diambil untuk menghasilkan per nyataan dan kesimpulan pada pemecahan masa lah yang tidak terbatas pada suatu bukti. Kemu dian, dia juga menyatakan bahwa ada dua jenis penalaran dalam pembelajaran matematika, yaitu penalaran induktif dan penalaran deduktif.

Penalaran induktif adalah kegiatan penarik an kesimpulan umum yang dilakukan berdasar kan data dan informasi yang bersifat khusus. Se dangkan penalaran deduktif adalah kegiatan pena rikan kesimpulan khusus berdasarkan aturan ter tentu. Selanjutnya NCTM (2000) menyatakan bahwa dalam menalarkan terdapat beberapa ke giatan yaitu mengembangkan ide, mengeksplo rasi fenomena, memberikan alasan atas suatu ja waban, dan membuat dugaan.

Pengetahuan awal mahasiswa menjadi da sar perkembangan kemampuan penalaran maha siswa. Muhammad (2017) menemukan bahwa ke mampuan penalaran tergantung pada pemahaman awal mahasiswa tersebut. Dalam matematika, ke mampuan awal ini dapat dikatakan pemahaman konsep. Jika mahasiswa tidak memahami konsep maka sudah pasti mahasiswa akan susah dalam menalarkan. Padahal dalam setiap mengerjakan masalah matematika, penalaran pasti diperlukan Riwayati (2019).

Terdapat enam indikator kemampuan pena laran matematis. Berdasarkan Pedoman Teknis Peraturan Dirjen Dikdasmen Depdiknas Nomor 506/C/Kep/PP/2004 yang dikutip oleh Wardhani (2008) bahwa ada keenam indikator kemampuan penalaran matematis yang harus dimiliki siswa adalah sebagai berikut: (1) kemampuan mengaju kan dugaan; (2) kemampuan melakukan manipu lasi matematika; (3) kemampuan menarik kesim pulan, menyusun bukti, memberikan alasan atau bukti terhadap kebenaran solusi; (4) kemampuan menarik kesimpulan dari pernyataan; (5) kemam puan memeriksa kesahihan suatu argumen; (6) ke mampuan menemukan pola atau sifat dari gejala matematis untuk membuat generalisasi.

Dengan kemampuan penalaran matematis yang baik, siswa ataupun mahasiswa memiliki keefektifan dan keefisiensian dalam menyelesai kan masalah matematika. Hal ini disebabkan sese orang berkemampuan panalaran matematis yang baik dapat memilih apa yang perlu dan apa yang tidak perlu dari suatu persoalan matematika. Se lain itu dia juga mampu menentukan koneksi an tar variabel yang diketahui pada soal hingga da pat menerapkan strategi penyelesaian masalah (Hidayat, 2020).

Jika dilihat fakta yang ada di lapangan, me nunjukkan bahwa kemampuan penalaran matema tis masih rendah. Data hasil studi pendahuluan yang dilakukan Ario (2017) di salah satu sekolah menengah kejuruan (SMK) di Pekanbaru, menun jukkan 95\% dari 72 siswa tidak dapat menjawab dengan benar ketika diberikan soal penalaran. Kemudian, data hasil penelitian Alpian (2020) di MTs Mathlaul Anwar Kecapi, Lampung menun jukkan bahwa berdasarkan hasil ulangan matema tika tahun pelajaran 2018/2019, diperoleh lebih 73\% dari 85 siswa juga memiliki kemampuan pe nalaran yang rendah.

Tidak hanya terjadi pada tingkat sekolah menengah, rendahnya kemampuan penalaran ma tematis juga terjadi di tingkat perguruan tinggi. Masih banyak mahasiswa yang belum mampu mengoptimalkan kemampuan penalaran matema tis. Faktanya, Haryono (2018) dalam penelitian nya mengungkapkan bahwa kemampuan penalar an induktif mahasiswa pendidikan matematika UNIPA bahwa dua dari tujuh indikator penalaran matematis tingkat ketercapaiannya masih kurang yaitu: (1) kemampuan menemukan pola atau sifat dari gejala matematis untuk membuat generali sasi, dan (2) kemampuan menarik kesimpulan da ri pernyataan.

Didukung data dari Adamura (2018) yang menyatakan kemampuan penalaran matematika mahasiswa di Indonesia masih rendah. Apalagi dalam mata kuliah yang diampunya yaitu Anali sis Real, kemampuan mahasiswa dalam menalar kan juga rendah. Mahasiswa kurang mampu ber pikir intuitif dalam memahami persoalan.

Indikasi rendahnya kemampuan penalaran matematis pada mahasiswa juga ditemukan pada 
artikel lainnya. Berdasarkan artikel yang dibuat Meryansumayeka (2013) diperoleh fakta dalam mata kuliah Telaah Kurikulum yang diampunya bahwa salah satu faktor penyebab hasil belajar mahasiswa belum memuaskan adalah kecende rungan mahasiswa menghafal materi. Kecende rungan ini disebabkan karena lemahnya kemam puan mahasiswa dalam menggunakan penalaran.

Selanjutnya, hasil Test of Logical Thinking (TOLT) yang dilakukan Rosita (2014) diperoleh bahwa $68 \%$ mahasiswa dikatagorikan pada level kemampuan penalaran rendah. Selanjutnya, Roha na (2015), menyatakan bahwa sebagai mahasis wa calon guru, tentunya harus memiliki kemam puan penalaran yang baik. Namun faktanya ratarata hasil pencapaian kemampuan penalaran matematis mahasiswa masih tergolong cukup, sementara peningkatannya tergolong sedang.

Fakta lain yang bersumber dari artikel dos en peneliti mata kuliah juga membuktikan bahwa kemampuan penalaran matematis mahasiswa di mana-mana bermasalah. Agustin (2016) mempe roleh fakta pada mata kuliah Metode Numerik kelas 2013A bahwa kemampuan penalaran maha siswa tersebut masih tergolong kurang. Beliau menjelaskan bahwa salah satu faktor yang penye babnya adalah logika berpikir mahasiswa yang masih rendah. Padahal logika dimanfaatkan da lam proses menalarkan. Pada waktu perkuliahan mata kuliah metode numerik, mahasiswa belum terlalu paham dengan materi yang disampaikan. Terlihat selama pembelajaran, mahasiswa mem butuhkan beberapa kali pertemuan sampai dapat memahami materi tertentu.

Pada tahun berikutnya, di tempat lain juga mengalami hal yang sama yaitu rendahnya ke mampuan penalaran matematis mahasiswa pada mata kuliah yang diampu dosen Himmi (2017) ju ga menyimpulkan kemampuan penalaran maha siswa mata kuliah Trigonometri masih sangat rendah. Mahasiwa kesulitan dalam membuktikan identitas trigonometri. Banyak mahasiswa yang memperoleh nilai rendah dan akhirnya memilih memperbaiki nilai pada semester pendek. Hal yang senada juga dilakukan Wahyuni (2017) dan ditemukan bahwa kemampuan pemahaman dan penalaran matematis mahasiswa tingkat IV mate ri Sistem Bilangan Kompleks pada mata kuliah Analisis Kompleks masih rendah di mana ratarata hanya mencapai $40 \%$. Kemudian Hariyani (2018) memberikan soal penalaran dalam Ujian Tengah Semester (UTS) dan Ujian Akhir Semes ter (UAS) mata kuliah Konsep Dasar Matematika kepada 101 mahasiswa. Diperoleh 64 orang dian taranya mendapat skor di bawah 70, sehingga ha sil akhir yang diperoleh mahasiswa rata-rata men dapatkan nilai $\mathrm{C}$.

Selanjutnya, Muhammad (2017) mengung kapkan fakta bahwa rata-rata kemampuan pena laran matematis mahasiswa tingkat III mata ku liah Struktur Aljabar II yang diampunya hanya $48.23 \%$. Kesulitan mahasiswa pada umumnya ya itu dalam menjawab soal pembuktian. Mahasis wa tidak dapat mengaplikasikan konsep atau teo rema yang telah dipelajari sebelumnya. Mereka tidak tahu bagaimana menggunakannya dan bah kan tidak tahu konsep atau teorema apa yang ha rus digunakan dalam membuktikan.

Dalam tiga tahun terakhir ini, fakta kemam puan penalaran matematis mahasiswa masih ren dah juga ditemukan. Adamura (2018) juga me nyimpulkan kemampuan penalaran matematika mahasiswa di Indonesia masih rendah. Terbukti dari hasil TIMSS dan hasil belajar mahasiswa ma ta kuliah Analisis Real yang diajarnya. Hal yang sama juga diutarakan oleh Arifendi (2019), bah wa dia menuliskan dalam kegiatan Trend in Inter national Mathematics and Science Study (TIM SS) pada tahun 2015, skor Indonesia pada bidang penalaran mateatika pada tahun tersebut hanya 20 dari skor rata-rata internasional yang mencapai 44. Sehingga hal ini membuktikan bahwa pena laran matematis siswa di Indonesia masih rendah. Kemudian, fakta yang ditemukan Yenni (2018) pada mata kuliah Teori Bilangan yang diampu nya, bahwa kemampuan penalaran adaptif maha siswa pendidikan matematika masih rendah. Hal ini ditandai dengan $84 \%$ mahasiswa kurang mam pu dalam menuliskan alasan yang logis pada se tiap langkah pembuktian yang dilakukan saat me ngerjakan soal. Di mana pada umumnya mahasis wa cenderung menghafalkan jawaban dan prose dur saja. Selanjutnya, Riwayati (2019) menemu kan bahwa kemampuan penalaran matematis ma hasiswa pada perkuliahan Pengantar Probabilitas juga masih rendah dan belum diperhatikan. Maha siswa belum terbiasa mengidentifikasi hal-hal penting dan ide utama dari materi yang dipelajari.

Berdasarkan fakta tersebut, diperlukanlah suatu penelitian yang bertujuan untuk mempero leh gambaran tentang kemampuan penalaran ma tematis mahasiswa Pendidikan Matematika UNP pada mata kuliah telaah kurikulum. Indikator ke mampuan penalaran matematis yang menjadi fo kus utama pada penelitian ini yaitu kemampuan mahasiswa membuat konjektur, menyusun bukti, memberikan alasan atau bukti terhadap kebe 
naran solusi, hingga kemampuan mahasiswa me narik suatu kesimpulan.

\section{METODE PENELITIAN}

Penelitian yang digunakan adalah peneli tian deskriptif. Disain yang digunakan merupa kan studi kasus (one shot case study). Dalam de sain ini, peneliti hanya memberikan treatment satu kali dan diasumsikan nantinya sudah meng hasilkan pengaruh sesuai topik yang diteliti (Aisyah, 2015). Dalam penelitian ini, treatment yang dimaksud adalah pemberian soal kuis ke mampuan penalaran matematis. Sedangkan kasus yang dideskripsikan dalam penelitian ini menge nai kemampuan penalaran matematis mahasiswa pendidikan matematika UNP pada mata kuliah telaah kurikulum matematika sekolah menengah. Penelitian ini dilakukan pada 36 mahasiswa se mester empat pendidikan matematika UNP pada mata kuliah telaah kurikulum matematika seko lah menengah. Pemilihan sampel ini dilakukan de ngan teknik purposive sampling.

Teknik pengumpulan data menggunakan ti ga metode yaitu: (1) metode wawancara; (2) ang ket; dan (3) tes tertulis. Instrumen tes tertulis beru pa soal tes penalaran matematis berbentuk uraian divalidasi dengan cara berdiskusi dengan sesama dosen jurusan matematika. Validasi yang dimak sud dalam hal ini adalah terkait ketepatan pemi lihan kata-kata pada soal tes yang tidak boleh am bigu, kesesuaian soal tes dengan indikator pena laran matematis, serta keberadaan pengetahuan dasar yang telah atau harus dimiliki oleh maha siswa pendidikan matematika semester empat. Se dangkan wawancara dan angket dijadikan seba gai teknik triangulasi data untuk pengecekan ke absahan data yang diperoleh.

Dalam menganalisis data kemampuan pe nalaran matematis, digunakanlah teknik analisis data model Milles dan Huberman. Ada empat prosedur dalam teknik analisis data model Milles dan Huberman antara lain: (1) mengumpulkan da ta; (2) mereduksi data; (3) menyajikan data atau menampilkan data; dan (4) membuat kesimpulan (Miles, 1994). Model analisis data Miles dan $\mathrm{Hu}$ berman ini dapat dilihat pada Gambar 1 .

Dalam penelitian ini, rincian tahapan anali sis data sebagai berikut: (1) mencatat seluruh hal yang terjadi selama perkuliahan melalui penga matan, wawancara, dokumentasi, dan tes; (2) me nelaah hasil pengamatan, wawancara, dokumen tasi, dan tes serta mengklasifikasikan data yang dianggap penting dan tidak penting (reduksi data); (3) mendeskripsikan data yang telah diklasi fikasikan dengan memperhatikan fokus dan tu juan penelitian; dan (4) membuat analisis akhir dalam bentuk laporan hasil penelitian.

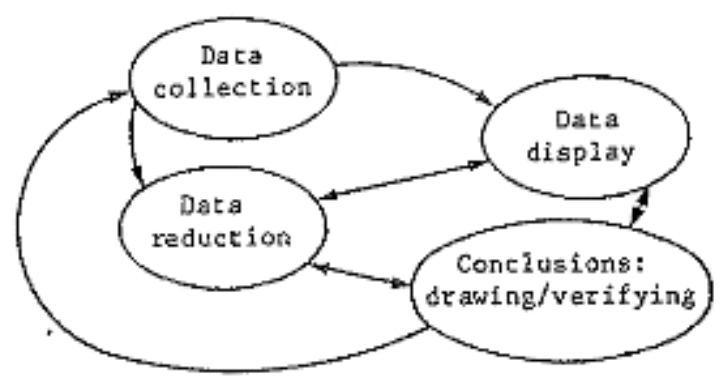

\section{Gambar 1. Analysis Interactive Model dari Miles \& Huberman (1994: 12)}

\section{HASIL DAN PEMBAHASAN}

Berdasarkan hasil kuis yang diberikan pa da 36 mahasiswa pendidikan matematika UNP di mata kuliah telaah kurikulum diperoleh hasil bah wa kemampuan penalaran mahasiswa pada indi kator menganalisis masalah, membuat konjektur, menentukan hubungan antar variabel, serta meng identifikasi kaitan antara proses atau konsep pada kasus yang diberikan juga masih rendah.

Rendahnya hasil kemampuan penalaran mahasiswa dapat dilihat dari jawaban mahasiswa dalam soal kuis penalaran. Berdasarkan analisis jawaban mahasiswa, diperoleh tiga tipe jawaban mahasiswa, antara lain:

1. Penyelesaian benar dengan membuat konjek tur, menentukan hubungan antar variabel, ser ta mengidentifikasi kaitan antara proses atau konsep tetapi tidak dapat memilih option jawaban yang benar.

2. Penyelesaian tidak dengan cara membuat kon jektur, tidak dengan cara menentukan hubung an antar variabel, serta tidak mengidentifika si kaitan antara proses atau konsep.

3. Salah dalam mengidentifikasi kaitan antara proses, konsep, atau variabel, sehingga jawab an salah.

Adapun soal kuis penalaran dapat dilihat pada Gambar 2. Jawaban yang benar dari soal adalah $a-b>1$ dengan option jawabannya :

\section{A. lebih besar daripada 1.}

Berdasarkan Gambar 3, penyelesaian ma hasiswa benar dengan membuat konjektur, me nentukan hubungan antar variabel, serta mengi 
dentifikasi kaitan antara proses atau konsep tetapi tidak dapat memilih option jawaban yang benar. Sehingga, mahasiswa menyimpulkan

$$
\text { "Jika } \mathrm{a}>5 \text { dan } \mathrm{b}<3 \text { maka nilai } \mathrm{a}-\mathrm{b}>2 \text { " }
$$

dengan benar tetapi mahasiswa tidak dapat memi lih option jawaban yang benar.

Jika $\mathrm{a}>5$ dan $\mathrm{b}<3$, maka nilai $\mathrm{a}-\mathrm{b}$ adalah...
A. lebih besar daripada 1
B. lebih besar daripada 3
C. lebih besar daripada 8
D. lebih kecil daripada 5
E. lebih kecil daripada 2

\section{Gambar 2. Soal Kuis Penalaran}

Hanya $17 \%$ mahasiswa yang benar dalam mengerjakan soal, akan tetapi salah dalam memi lih option jawaban yang benar (jawaban Tipe I). Seharusnya berdasarkan sifat himpunan dan sifat urutan bilangan real, jika $\mathrm{a}-\mathrm{b}>2$ maka pasti $\mathrm{a}-\mathrm{b}>1$. Sehingga dapat disimpulkan bahwa: Jika $\mathrm{a}>5$ dan $\mathrm{b}<3$, maka $\mathrm{a}-\mathrm{b}>2$. Jawaban yang tepat adalah

A. lebih besar daripada 1 .

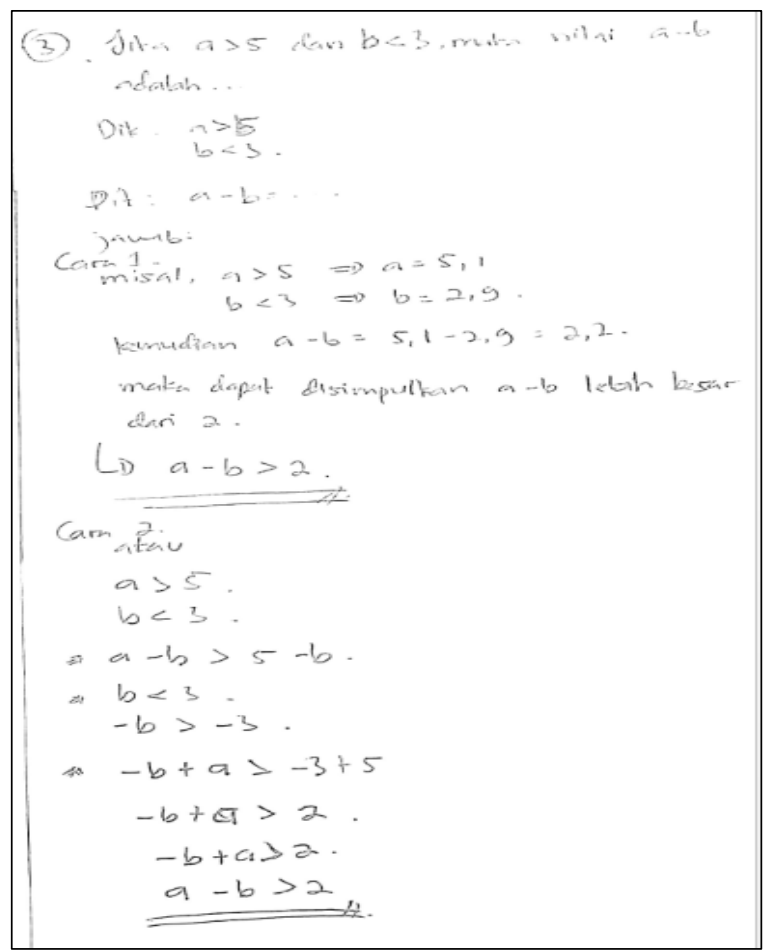

Gambar 3. Salah Satu Jawaban Mahasiswa Tipe I

Berdasarkan hasil wawancara dengan ma hasiswa tipe jawaban I, disimpulkan bahwa mere ka memahami maksud soal dan meyakini bahwa penyelesaiannya benar. Akan tetapi ketika memi lih jawaban, mereka menjadi ragu. Seharusnya, ji kalau kemampuan analisis mahasiswa bagus, ten tunya mahasiswa dapat menyimpulkan jawaban yang tepat.

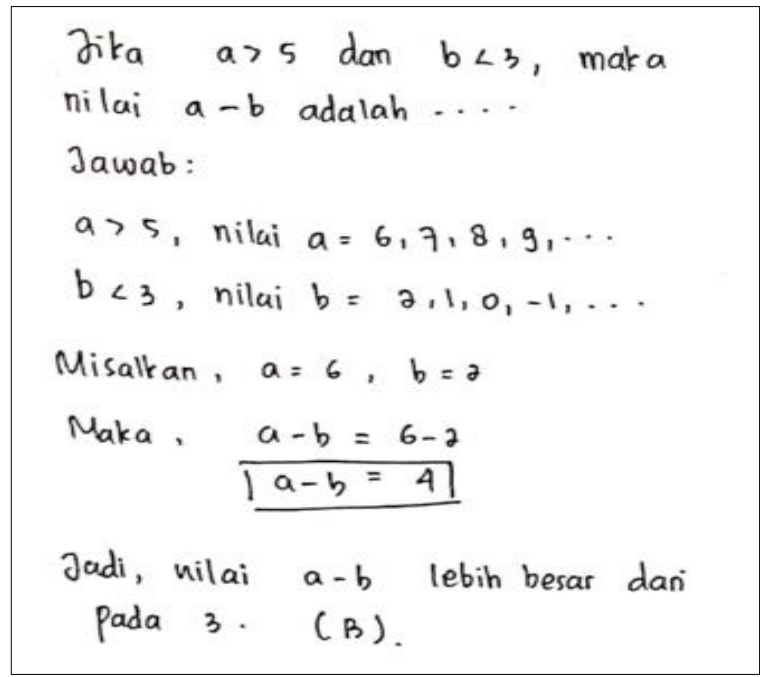

\section{Gambar 4. Salah Satu Jawaban Mahasiswa Tipe II}

Berdasarkan Gambar 4, dapat dilihat cara ini tidak salah. Akan tetapi, belum pasti kesim pulannya berlaku umum. Hal ini dikarenakan ma hasiswa hanya memilih beberapa anggota him punan bilangan a dan $\mathrm{b}$ saja, kemudian mencari nilai a - b. Sehingga, pada umumnya mahasiswa menyimpulkan:

"Jika a $>5$ dan $\mathrm{b}<3$ maka nilai $\mathrm{a}-\mathrm{b}>3$ "

"Jika $\mathrm{a}>5$ dan $\mathrm{b}<3$ maka nilai $\mathrm{a}-\mathrm{b}>4$ "

"Jika $\mathrm{a}>5$ dan $\mathrm{b}<3$ maka nilai $\mathrm{a}-\mathrm{b}>5$ "

Tentunya kesimpulan ini memiliki perbedaan (ga lat) yang besar dibandingkan dengan jawaban se benarnya.

Sebanyak $71 \%$ menjawab dengan cara se perti Gambar 4. Disimpulkan bahwa mahasiswa sama sekali tidak memperlihatkan kemampuan bernalarnya. Hal ini dikarenakan mahasiswa ti dak mampu membuat konjektur dari yang diketa hui di soal, tidak mampu menentukan hubungan antar variabel soal, serta tidak mampu mengiden tifikasi kaitan antara proses atau konsep yang ada pada soal. Seharusnya mahasiswa mampu mene mukan kaitan antara $\mathrm{a}>5$ dan $\mathrm{b}<3$ dengan $\mathrm{a}-\mathrm{b}$. Akan tetapi, mahasiswa hanya menyelesaikan so al dengan cara mencoba beberapa anggota him punan bilangan a dan $b$ kemudian mencari nilai $\mathrm{a}-\mathrm{b}$, selanjutnya menyimpulkan nilai $\mathrm{a}-\mathrm{b}$ berda sarkan nilai yang diperoleh (jawaban Tipe II).

Berdasarkan hasil wawancara dengan ma hasiswa tipe jawaban II, disimpulkan bahwa ma hasiswa memahami maksud soal, tetapi mengang 
gap cara yang dipakai sudah dapat memberikan kesimpulan umum. Mahasiswa sudah mengguna kan logika berpikir yang benar tetapi belum mak simal. Dari wawancara dapat diambil kesimpulan bahwa telah terjadi proses penalaran, meskipun belum tepat dan optimal.

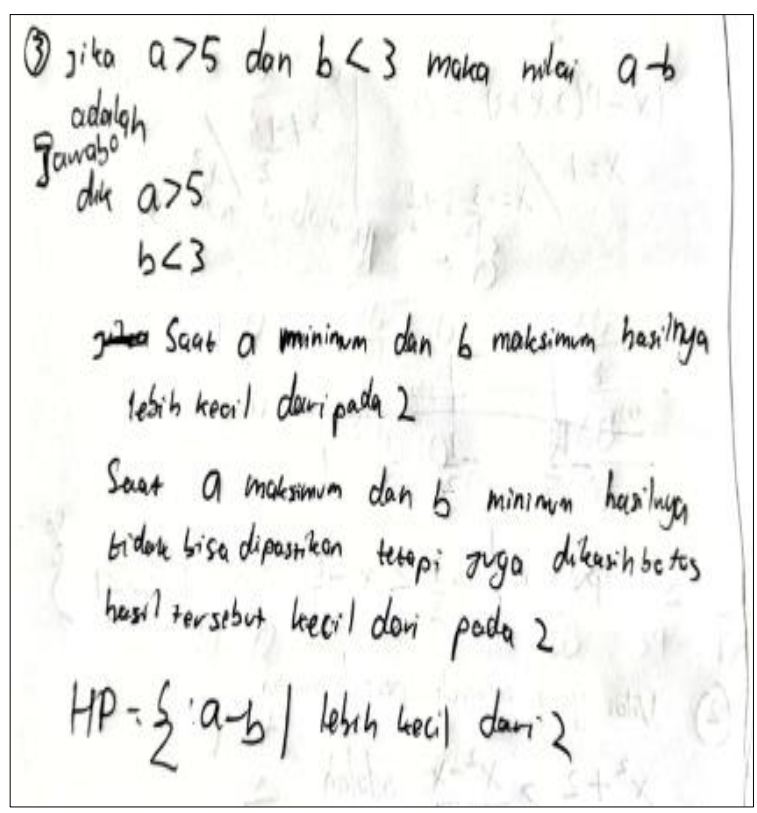

Gambar 5. Salah Satu Jawaban Mahasiswa Tipe III

Berdasarkan Gambar 5, dapat dilihat maha siswa belum mampu dalam mengidentifikasi kaitan antara proses, konsep, atau variabel, se hingga jawaban salah. Hanya $12 \%$ mahasiswa menjawab seperti tipe jawaban III. Mereka salah dalam mengidentifikasi kaitan antara proses, kon sep, atau variabel pada soal, sehingga walaupun mahasiswa berusaha memberikan jawaban, tetapi pemahaman dasarnya salah. Hal ini membukti kan kebenaran teori yang dijelaskan Muhammad (2017) bahwa pemahaman awal adalah hal terpen ting dalam menalarkan.

Menurut hasil wawancara dengan mahasis wa tipe jawaban III, disimpulkan bahwa maha siswa sama sekali tidak memiliki kemampuan menganalisis. Bahkan, mahasiswa salah dalam memahami konsep. Mereka mengakui kebingung an dalam memilih bilangan a dan b karena bilangannya cukup banyak. Sehingga rata-rata mahasiswa menyelesaikan hanya dalam bentuk kata-kata atau kalimat penjelasan saja.

Ringkasan persentase ketiga tipe jawaban mahasiswa tersebut dapat dilihat pada Tabel 1 . Berdasarkan Tabel 1, dapat dilihat kemampuan penalaran matematis mahasiswa masih rendah. Ti dak ada seorang mahasiswa pun yang dapat memi lih option jawaban yang benar pada soal tersebut.
Akan tetapi, jika soalnya bukan berupa pilihan berganda, dapat dikatakan ada walaupun sedikit mahasiswa yang menjawab benar soal tersebut dengan menunjukkan penalaran yang baik.

Tabel 1. Persentase Tipe Jawaban Mahasiswa

\begin{tabular}{|c|c|c|}
\hline No. & Tipe Jawaban & Persentase \\
\hline 1 & I & 17 \\
\hline 2 & II & 71 \\
\hline 3 & III & 12 \\
\hline
\end{tabular}

Hasil penelitian ini juga dikaitkan dengan penelitian-penelitian terdahulu. Penelitian yang dilakukan Meryansumayeka (2013) berfokus pa da "Pendesainan Pembelajaran Menggunakan Pendekatan Analisis Nilai Pada Mata Kuliah Te laah Kurikulum". Kaitannya adalah penelitian ini sama-sama melihat nilai-nilai penalaran yang mencakup akurasi, kejelasan, conjecturing, kon sistensi, kreativitas, dan sistematis mahasiswa da lam mengerjakan soal. Nilai-nilai ini memang ter bukti dapat mengungkap kemampuan penalaran mahasiswa. Apabila dikaitkan dengan penelitian yang dilakukan Pamungkas (2016), hasil kemam puan penalaran matematis mahasiswa yang ren dah ini dapat diatasi dengan mengembangkan ba han ajar. Sejalan dengan itu, Fisher (2017) juga membuktikan bahwa kemampuan penalaran mate matis mahasiswa calon guru matematika dapat di tingkatkan melalui blended-learning dengan stra tegi probing-prompting.

Hal yang menjadi perhatian untuk peneli tian berikutnya, yaitu diperlukan penelitian yang mampu meningkatkan kemampuan penalaran ma tematika mahasiswa. Penelitian yang diperlukan yaitu dengan cara: (1) penerapan strategi, pende katan, atau model pembelajaran atau (2) pengem bangan perangkat pembelajaran. Sehingga, diha rapkan kemampuan penalaran yang mereka capai terjadi peningkatan.

\section{KESIMPULAN}

Berdasarkan hasil dan pembahasan peneli tian, dapat disimpulkan bahwa kemampuan pe nalaran matematis mahasiswa pendidikan mate matika UNP pada pada mata kuliah telaah kuriku lum matematika sekolah menengah di semester empat masih rendah. Di mana indikator kemam puan penalaran matematis yang rendah yaitu pa da kemampuan mahasiswa membuat konjektur dari variabel yang diketahui pada soal, menyusun bukti, memberikan alasan atau bukti terhadap kebenaran solusi, hingga kemampuan menarik kesimpulan masih tergolong sangat rendah. Perlu 
(Kemampuan Penalaran Mahasiswa dalam Memecahkan Masalah .......) 153

dilakukan upaya-upaya dalam meningkatkan ke mampuan penalaran matematis mahasiswa mata kuliah telaah kurikulum matematika sekolah me nengah agar kualitas pembelajaran di sekolah dan pendidikan berkualitas.

\section{DAFTAR PUSTAKA}

Adamura, Fatriya., Susanti, Vera Dewi. 2018. Pe nalaran Matematis Mahasiswa dengan Ke mampuan Berpikir Intuitif Sedang dalam Memecahkan Masalah Analisis Real. JEMS (Jurnal Edukasi Matematika dan Sains), 6(2): 77-92.

Afri, Lisa Dwi. 2019. Pengembangan Soal Tes Kemampuan Representasi Dan Penalaran Matematis Serta Skala Sikap Self Concept Untuk Siswa SMP. Jurnal Axiom, 8(1): 12.

Agustin, Ririn Dwi. 2016. Kemampuan Penalar an Matematika Mahasiswa Melalui Pende katan Problem Solving. Jurnal Pedagogia, 5(2): 179-188.

Aisyah, Nur Lindah. 2015. Penerapan Model Pembelajaran Kooperatif Tipe Make A Match Untuk Meningkatkan Hasil Belajar Siswa Kelas X Jasa Boga Pada Kompe tensi Dasar Potongan Bahan Makanan Di Smk Negeri 1 Cerme, Gresik. e-journal Boga, 4(1): 143-152.

Alpian, Rudi., Anggoro, Bambang Sri. 2020. Stu dents' Mathematical Reasoning Analysis Based on Van Hiele Theory. Indonesian Journal of Science and Mathematics Edu cation, 3(1): 97.

Arifendi, Rio Febriant., Rudy, Setiawan. 2019. Upaya Peningkatan Penalaran Matematis Mahasiswa Universitas Tribhuwana Tung gadewi Melalui Pendekatan Contextual teaching and learning (CTL). Prismatika: Jurnal Pendidikan dan Riset Matematika, 1(2): 55-59.

Arigiyati, Tri Astuti. 2017. Matematis Model Learning Cycle Dan Konvensional Pada Kuliah Statistika Matematika II. Jurnal Math Educator Nusantara (JMEN), 3(1): 43-44.

Ario, Marfi. 2017. Perbandingan Peningkatan Kemampuan Penalaran Matematis Antara Pembelajaran Berbasis Masalah Dan Pe nemuan Terbimbing Ditinjau Dari Kemam puan Awal Matematis Siswa. Jurnal Eksak ta Pendidikan (JEP), 1(2): 86-92.
Aziz, Saddam Al. 2018. The Influence of Mathe matical Learning Material Based On Mo del-Eliciting Activities (MEAs) Approach To Improve Mathematical Creative Think ing Skill Of Students Of Grade X Of Senior High School Padang. Proceedings. Atlant is Press, Vol 285: 117.

Fahyuddin,. Sampradja, Hafi Ludin. 2015. Ekspl orasi Kemampuan Penalaran Mahasiswa Melalui Pemecahan Masalah Kimia Seca ra Terstruktur. Jurnal Pendidikan dan Pem belajaran, 22(2): 152.

Fisher, Dahlia. 2017. Peningkatan Kemampuan Penalaran Matematis Mahasiswa Calon Guru Matematika Melalui Blended-Learn ing Dengan Strategi Probing-Prompting. Pasundan Journal of Research in Mathe matics Learning and Education (Symmet ry), 2(2): 78-86.

Hariyani, Mimi., Amir, Zubaidah. 2018. Pening katan Kemampuan Penalaran Matematis Mahasiswa Pendidikan Guru Madrasah Ibtidaiyah Melalui Concept Attainment Model. Journal of Madrasah Ibtidaiyah Education, 2(1): 119-130.

Haryono, Agus., Tanujaya, Benediktus. 2018. Profil Kemampuan Penalaran Induktif Ma tematika Mahasiswa Pendidikan Matema tika Unipa Ditinjau Dari Gaya Belajar. Journal Of Honai Math, 1(2): 127-138.

Helma. Edizon. 2020. Faktor-Faktor yang Mem pengaruhi Hasil Belajar Matematika Sis wa Untuk Penerapan Bahan Ajar Kon tekstual Mengintegrasikan Pengetahuan Terkait Dan Realistik. Jurnal Eksakta Pendidikan (JEP), 1(1): 86-92.

Hidayat, Wahyu., Sariningsih, Ratna. 2020. Pro fil Kemampuan Penalaran Kreatif Matema tis Mahasiswa Calon Guru. Jurnal Elemen. 6(1): 108-127.

Himmi, Nailul. 2017. Korelasi Self Efficacy Ter hadap Kemampuan Penalaran Matematis Mahasiswa Semester Pendek Mata Kuliah Trigonometri UNRIKA. Jurnal Pythagoras, 6(2): $143-150$.

Meryansumayeka. 2013. Pendesainan Pembel ajaran Menggunakan Pendekatan Analisis Nilai Pada Mata Kuliah Telaah Kuriku lum. Jurnal Pendidikan Matematika, 7(1): $1-10$.

Miles, M. B., Huberman, M. A. 1994. Qualitative Data Analysis: An Expanded Sourcebook $(2 r d e d)$. London: Sage Publication. 
Muhammad, Guntur Maulana. 2017. Analisis Ke mampuan Penalaran Matematis Mahasis wa Pada Mata Kuliah Struktur Aljabar II (Teori Gelanggang). Jurnal Prisma, 6(1): 66-78.

NCTM. 2000. Focus in High School Mathema tics: Reasoning and Sense Making. Reston, VA: The National Council of Teachers of Mathematics, Inc.

NCTM. 2000. Principle and Standards for School Mathematic. Virginia: NCTM, diak ses pada https://www.nctm.org/, hal 4.

Nuh, Muhammad. 2014. Modul Pelatihan Im plementasi Kurikulum 2013. Jakarta: Ba dan Pengembangan Sumber Daya Manusia Pendidikan dan Kebudayaan dan Penja minan Mutu Pendidikan Kementerian Pendidikan dan Kebudayaan 2013.

Pamungkas, A. S. 2016. Pengembangan Bahan Ajar Untuk Peningkatan Kemampuan Pe nalaran Matematis Mahasiswa Calon Guru Matematika. JPPM , 9 (2), 177-182.

Riwayati, Selvi., Destania, Yuriska. 2019. Efek tifitas Desain Lembar Kerja Mahasiswa (LKM) Terintegrasi Internet untuk Me ngembangkan Kemampuan Penalaran Ma tematis Mahasiswa. EDUMATIKA: Jur nal Riset Pendidikan Matematika, 2(2): 104-112.

Rohana. 2015. Peningkatan Kemampuan Pena laran Matematis Mahasiswa Calon Guru Melalui Pembelajaran Reflektif. Jurnal Ilmiah Infinity, 4(1): 105-119.

Shadiq, Fadjar. 2004. Pemecahan Masalah, Pena laran dan Komunikasi. Yogyakarta: PPPG Matematika.

Sumartini, Tina Sri. 2015. Peningkatan Kemam puan Penalaran Matematis Siswa melalui Pembelajaran Berbasis Masalah. Jurnal Pendidikan Matematika. 5(1): 1-2.

Wahyuni, Ika., Karimah, Nurul Ikhsan. 2017. Analisis Kemampuan Pemahaman Dan Pe nalaran Matematis Mahasiswa Tingkat IV Materi Sistem Bilangan Kompleks Pada Mata Kuliah Analisis Kompleks. Jurnal JNPM (Jurnal Nasional Pendidikan Mate matika), 1(2): 228-240.

Yenni,. Rachma, Eka. 2018. Pengembangan Lem bar Kerja Mahasiswa berbasis Inquiry Un tuk Mengoptimalkan Kemampuan Penalar an Adaptif. Jurnal Analisa, 4(2): 61-71. 